\title{
LOVASTATIN REDUCES NEURONAL CELL DEATH IN HIPPOCAMPAL CA1 SUBFIELD AFTER PILOCARPINE-INDUCED STATUS EPILEPTICUS
}

\section{Preliminary results}

\author{
Pauline Rangel', Roberta Monterazzo Cysneiros' ${ }^{2}$ Ricardo Mario Arida ${ }^{1,2}$, \\ Marly de Albuquerque1, Diego Basile Colugnati,2, Carla Alessandra Scorza², \\ Esper Abrão Cavalheiro², Fulvio Alexandre Scorza ${ }^{1,2}$
}

\begin{abstract}
Objective: To further characterize the capacity of lovastatin to prevent hippocampal neuronal loss after pilocarpine-induced status epilepticus (SE) Method: Adult male Wistar rats were divided into four groups: (A) control rats, received neither pilocarpine nor lovastatin $(n=5) ;(B)$ control rats, received just lovastatin $(n=5)$; (C) rats that received just pilocarpine $(n=5)$; (D) rats that received pilocarpine and lovastatin $(n=5)$. After pilocarpine injection $(350 \mathrm{mg} / \mathrm{kg}$, i.p.), only rats that displayed continuous, convulsive seizure activity were included in our study. Seizure activity was monitored behaviorally and terminated with an injection of diazepam (10 mg/kg, i.p.) after $4 \mathrm{~h}$ of convulsive SE. The rats treated with lovastatin received two doses of $20 \mathrm{mg} / \mathrm{kg}$ via an oesophagic probe immediately and 24 hours after SE induction. Seven days after pilocarpine-induced SE, all the animals we reperfused and their brains were processed for histological analysis through Nissl method. Results: The cell counts in the Nissl-stained sections performed within the hippocampal formation showed a significant cell loss in rats that received pilocarpine and presented $S E(C A 1=26.8 \pm 13.67 ; C A 3=38.1 \pm 7.2$; hilus $=43.8 \pm 3.95)$ when compared with control group animals (Group A: $C A 1=53.2 \pm 9.63$; $C A 3=63.5 \pm 13.35$; hilus $=59.08 \pm 10.24$; Group $B: C A 1=74.3 \pm 8.16$; $C A 3=70.1 \pm 3.83$; hilus $=70.6 \pm 5.10$ ). The average neuronal cell number of $C A 1$ subfield of rats that present SE and received lovastatin $(44.4 \pm 17.88)$ was statically significant increased when compared with animals that just presented SE. Conclusion: Lovastatin exert a neurop rotective role in the attenuation of brain damage after SE.
\end{abstract}

KEY WORDS: epilepsy, pilocarpine, lovastatin, hippocampus.

\begin{abstract}
Lovastatina reduz a lesão celular na região CA1 do hipocampo após o status epilepticus induzido pela pilocarpina: resultados preliminares

RESUMO - Objetivo: Capacidade da lovastatina em prevenir a perda de neurônios hipocampais após o status epilepticus (SE) induzido pela pilocarpina. Método: Ratos adultos Wistar foram divididos em 4 grupos: (A) ratos controles que não receberam pilocarpina nem lovastatina $(n=5)$; $(B)$ ratos controles que receberam somente lovastatina $(n=5)$; $(C)$ ratos que receberam somente pilocarpina $(n=5) ;(D)$ ratos que receberam pilocarpina e lovastatina $(n=5)$. Após a administração de pilocarpina (350mg/kg, i.p.), somente ratos que evoluíram para o status epilepticus foram incluídos em nosso estudo. A atividade epiléptica foi interrompida com uma injeção de diazepam (10 mg/kg, i.p.) após $4 \mathrm{~h}$ do início do SE. Os ratos tratados com lovastatina receberam duas doses de $20 \mathrm{mg} / \mathrm{kg}$ via esofágica, imediatamente e 24 h após a indução do SE. Sete dias após o SE induzido pela pilocarpina, todos os animais foram perfundidos e seus cére b ros processados para análise histológica através do método de Nissl. Resultados: A contagem celular da formação hipocampal mostrou uma significante perda celular nos animais que receberam pilocarpina e apresentaram $S E(C A 1=26,8 \pm 13,67$; $C A 3=38,1 \pm 7,2$; hilus= 43,8 $\pm 3,95)$ quando comparados com animais pertencentes ao grupo controle (Grupo $A$ : $C A 1=53,2 \pm 9,63$; $C A 3=63,5 \pm 13,35$; hilus= $59,08 \pm 10,24 ;$ Grupo B: $C A 1=74,3 \pm 8,16$; $C A 3=70,1 \pm 3,83$; hilus=70,6 $\pm 5,10)$. O número de células neuronais na região CA1 do hipocampo de ratos que apresentaram SE e receberam lovastatina $(44,4 \pm 17,88)$ foi estatisticamente maior quando comparado com animais que somente apresentaram SE. Conclusão: A lovastatina exerce papel neuroprotetor na atenuação do dano cerebral após o SE.
\end{abstract}

PALAVRAS-CHAVE: epilepsia, pilocarpina, lovastatina, hipocampo.

\footnotetext{
'Laboratório de Neurociências, Núcleo de Pesquisas Tecnológicas/Universidade de Mogi das Cruzes (NPT/ UMC), Mogi das Cruzes SP, Brazil; ${ }^{2}$ Laboratório de Neurologia Experimental, Universidade Federal de São Paulo/Escola Paulista de Medicina (UNIFESP/EPM), São Paulo SP, Brazil. FAEP, FAPESP, CNPq and CAPES supported this study.

Received 30 May 2005, received in final form 27 July 2005. Accepted 19 August 2005.

Dr. Fulvio Alexandre Scorza - Rua Botucatu 862 - Ed. Leal Prado, Disciplina de Neurologia Experimental / UNIFESPIEPM - 04023-900 São Paulo SP - Brasil. E-mail: scorza.nexp@epm.br
} 
Status epilepticus (SE), a neurological emergency characterized by abnormally prolonged seizures, remains an important clinical problem ${ }^{1}$. Animal models of SE have been used to produce chronic epilepsy, thus suggesting that SE itself is epileptogenic ${ }^{2}$. The systemic administration of a potent agonist pilocarpine to rats leads to a pattern of repetitive limbic seizures and SE, which can last for up 12 hours ${ }^{3,4}$. Morphological analysis of hippocampal formation after pilocarpine-induced SE shows an extensive loss of neurons within the hilar area of the dentate gyrus ${ }^{4,5}$, as well a loss of selective populations of interneurons in areas CA 1 and CA3 and in the hilus ${ }^{4}$. Furthermore, SE-associated cell loss is a critical step that activates a cascade of events leading to mossy fiber sprouting, de novo recurrent excitation of granule cells, culminating in spontaneous recurrent seizures (SRSs) ${ }^{4-6}$.

Lovastatin, a fungal antibiotic used in hyperchole st e rolemia treatment, is a competitive inhibitor of HMG-CoA (3-hydroxy-3-methylglutaryl coenzime A reductase), the major regulatoryenzyme of $d e$ novo cholesterol synthesis ${ }^{7}$. Recent data reveal that statins reduce vascular inflammatoryresponses ${ }^{8}$, promote angiogenesis ${ }^{9}$, modulate cytokine production ${ }^{10}$ and decrease oxidative stress ${ }^{11}$. Furthermore, recent studies have shown that statins reduces the extent of brain damage after ischemic insult ${ }^{12}$.

Based on this, the purpose of our study was to further characterize the capacity of lovastatin to prevent hippocampal neuronal loss after pilocarpine-induced status epilepticus.

\section{METHOD}

Adult male Wistar rats $(n=20)$, weighting $200-250 \mathrm{~g}$ we re housed under standard controlled conditions (7:00 AM/7:00 P.M. light/dark cycle; $20-22^{\circ} \mathrm{C} ; 45-55 \%$ humidity) with food and water ad libitum we re used in our study. The procedures involving the animals and their care at the Neuroscience Laboratory at University of Mogi das Cruzes respected the Institution's guidelines, which comply with national and international rules and policies. Rats were divided randomly into four groups: $(A)$ control rats, received neither pilocarpine nor lovastatin $(n=5)$; (B) control rats, received just lovastatin $(n=5)$; $(C)$ rats that received just pilocarpine $(n=5)$; $(D)$ rats that received pilocarpine and lovastatin $(n=5)$.

SE were induced according to the procedure described previously 4 . In brief, 30 minutes after methylscopolamine injection $(1 \mathrm{mg} / \mathrm{kg}$, s.c - used to reduce peripheral effects of pilocarpine), pilocarpine (350 mg/kg, i.p.) was administered to rats. Only rats that displayed continuous, convulsive seizure activity after pilocarpine treat- ment were included in these studies. Seizure activity was monito redbehaviorally and terminated with an i.p. injection of diazepam (10 mg/kg; Roche, Brazil) after $4 \mathrm{~h}$ of convulsive SE. Lovastatin was provided by Millenium Pharmacy (São Paulo, Brazil) and was diluted using sterile saline $0,9 \%$. The rats treated with lovastatin received two doses of $20 \mathrm{mg} / \mathrm{kg}$ via an oesophagic probe immediately and 24 hours after SE induction.

Seven days after pilocarpine-induced SE, the animals we reperfused and the brains were processed for histological analysis. Sections cut $20 \mu \mathrm{m}$ thick were stained according to Nissl method. Cell counts in the Nissl-stained sections, were performed within the hippocampal pyramidal cell layer and the dentate hilus, as previously reported by Mouritzen-Dam ${ }^{13}$. For each animal, both the right and left hemispheres of three different sections we re counted to provide a total of five individuals values per animal. Only cells with evident nucleus and nucleolus were included in the counts. The mean value observed in control rats was considered $100 \%$ of normal cell population. Statistical analysis was perf o rmed by one-way analysis of variance (ANOVA), followed by post-hoc Dunnett's test; $p$ values of $p<0.05$ were considered statically significant.

\section{RESULTS}

Pilocarpine treatment induced the following behavioral changes: akinesia, facial automatisms, and limbic seizures consisting of forelimb clonus with rearing, salivation, and masticatory jaw movements and falling. This type of behavior built up progressively into motor limbic seizures that rec u rred repeatedly and rapidly and developed into SE. After SE, animals were comatose or unresponsive to their environment and akinetic; behavior returned toward normal over a 3 to 5-day period.

We next analyzed the qualitative morphological changes in the hippocampus associated with lovastatin treatment and SE. In the control animals (Fig 1A, 1B), the Nissl staining of hippocampal formation and dentate gyrus showed integrity of all cells layers. In contrast, animals that received just pilocarpine and presented SE (Fig 1C) we observed a significant cell loss in hippocampal subfields CA1, CA3 and hilus of dentate gyrus. Interesting, the structural analysis of the brains from animals that presented SE and received lovastatin (Fig 1D) was similar when compa red with animals in the control group.

From a quantitative point of view, Fig 2 shows cell counts in the Nissl-stained sections performed within the hippocampal pyramidal cell layer (CA1 and (A3) and the dentate hilus. A significant cell loss was observed in rats that received pilocarpine 


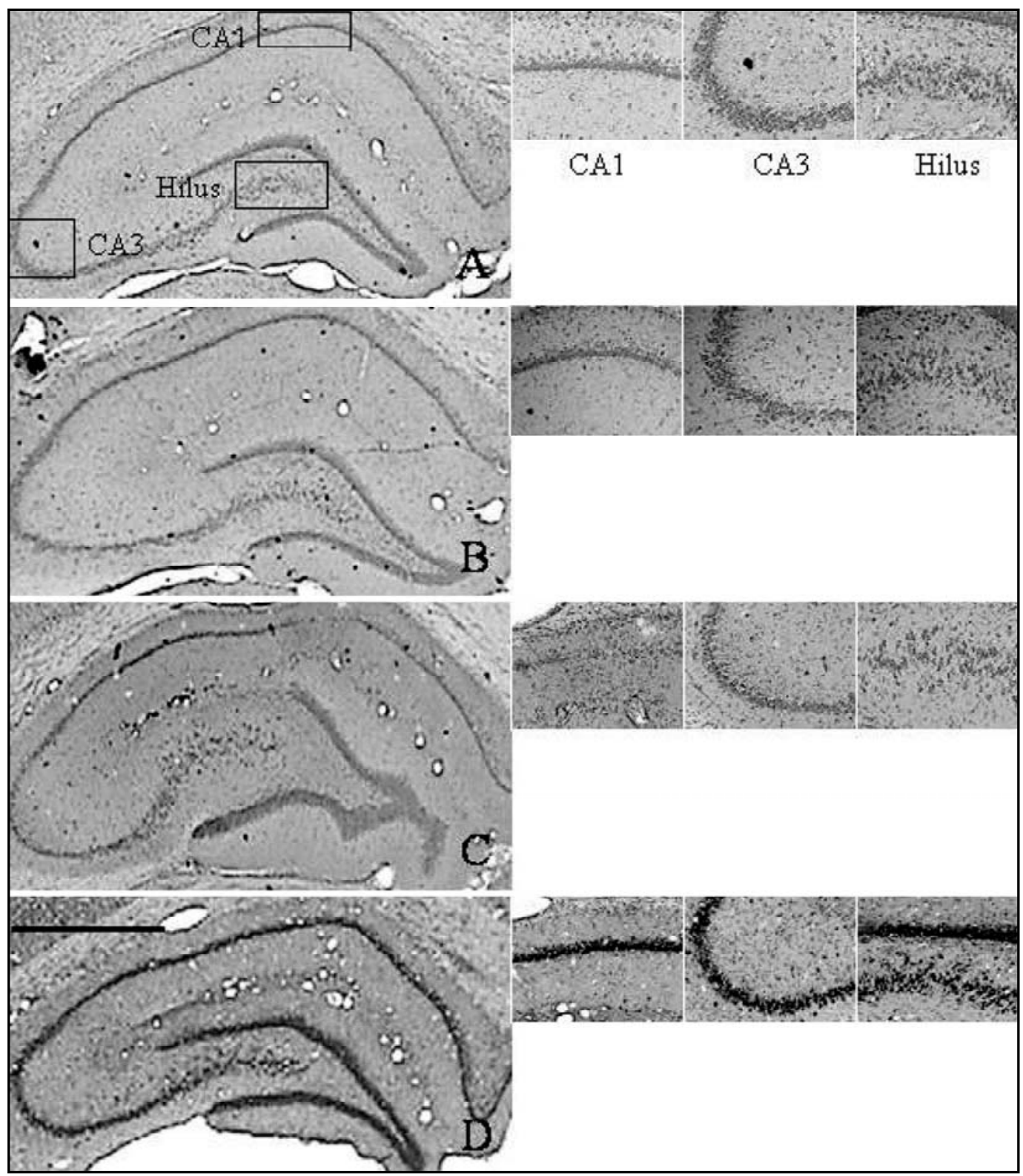

Fig 1. Nissl staining of hipocampal formation. Photomicrograph of hipocampal formation showing: (A) control rats, received neither pilocarpine nor lovastatin; $(B)$ control rats, received just lovastatin; (C) rats that received just pilocarpine; $(D)$ rats that received pilocarpine and lovastatin. Scale bar: $600 \mu \mathrm{m}$

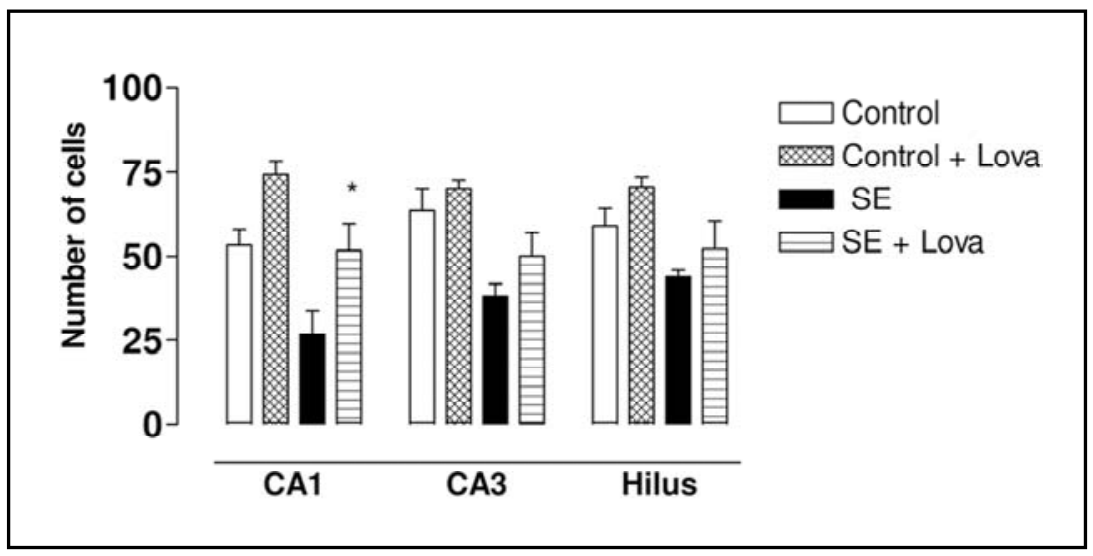

Fig 2. Neuronal cell count. Data represent average neuronal cell counts in control rats, rats that received just pilocarpina and rats that received pilocarpine and lovas tatin. Data were analyzed by ANOVA, fol lowed by post hoc Dunnett's test. Note the reduced cell loss in CA1 subfield of rats that received pilocarpine and lovastatin when compared with rats that just received pilocarpina. Data expressed as mean $\pm S$.E. ${ }^{*} p<0.05$. 
and presented SE $(C A 1=26.8 \pm 13.67 ;$ CA3 $=38.1 \pm$ 7.2; hilus $=43.8 \pm 3.95)$ when compared with control group animals (Group A: CA1 $=53.2 \pm 9.63$; CA3 $=63.5 \pm 13.35$; hilus $=59.08 \pm 10.24$; Group B: $\mathrm{CA} 1=74.3 \pm 8.16 ; \mathrm{CA} 3=70.1 \pm 3.83 ;$ hilus $=70.6 \pm$ 5.10). The average neuronal cell number of CA1 subfield of rats that present SE and received lovastatin $(44.4 \pm 17.88)$ was statistically significant increased when compared with animals that just presented SE. It is therefore of interest that the cells in CA3 subfield and hilus of rats that present SE and received lovastatin (CA3= $50.14 \pm 15.33$; hilus= $52.20 \pm 18.71$ ) tended to be relatively protect when compared with animals that just received pilocarpine and presented SE.

\section{DISCUSSION}

This study evaluated the effects of lovastatin administration in rats after pilocarpine-induced SE. We demonstrated that lovastatin treatment was able to prevent hippocampal neuronal loss in CA1 subfield after an epileptic insult. In these lines, our results are in agreement with a recent study that re$p$ o rted an effective neuro $p$ rotective action of statins after an acute brain injury ${ }^{14}$.

Reactive oxygen species (ROS) are a part of normal human metabolism; however, when produced in excess, ROS can cause tissue injury including lipid peroxidation, DNA damage and enzyme inactivation $^{8}$. ROS is a common denominator among acute neurdogical conditions ${ }^{8,15}$, including epilepsy ${ }^{16,17}$. In the pilocarpine model, there is a involvement of excitotoxic neuronal injury ${ }^{18}$ and ROS production has been considered to be a part of mechanisms involved with glutamatergic excitotoxicity in vitro ${ }^{15}$ and in vivo ${ }^{16,17,19}$. Moreover, it was demonstrated that lovastatin treatment inhibits free radical injury ${ }^{20}$. Thus, this antioxidant effect of statins could explain the neuroprotective properties found in our study.

There is one classical argument supporting a possible role of nitric oxide (NO) in convulsive phenomena: excitatory amino acids, such as N-methylD- aspartate (NMDA) and kainate, are known to be potent convulsants ${ }^{21}$, and the activation of NMDA receptors is accompanied by the formation of $\mathrm{NO}^{22}$. In fact, the role of NO in epileptogenesis has been examined in a number of studies, suggesting to be a proconvulsive endogenous substance ${ }^{23,24}$. Furthe rmore, some studies have revealed that statins inhibit the production of NO in brain parenchyma ${ }^{10}$, indicating that statins, secondarily, may play the role of an anticonvulsant substance, does not promoting glutamate-mediated neurotoxicity. Other possibility is that the inhibition of brain endothelial nitric oxide synthase (eNOS) leads to increased blood pressure ${ }^{25}$, which, in turn, may affect the excitability of central nervous system ${ }^{26}$; however, it was demonstrated that statins are able to upre gulate eNOS ${ }^{27}$, may be pivotal in enhance cerebral arterial vasodilator responses, decreasing with this, the firing threshold.

Finally, anti-inflammatory effects of statins could also contribute to neuroprotection after pilocarpine-induced SE observed in our study. The pathological alterations that occur in the hippocampus following prolonged seizures begin within hours and cause changes that last throughout life. Moreover, several studies has implicated a number of cytokines in seizure-related hippocampal pathology ${ }^{28,29}$. Interestingly, Pahan and colleagues ${ }^{10}$ have been shown that lovastatin reduces the induction of inflammatory mediators. Taken together, lovastatin treatment may provide an important approach to suppression of the inflammatory responses after SE induced by pilocarpine.

Based on these facts, our preliminaryresults support previous evidence that statins reduces neuronal death after an acute brain insult. Future studies are needed to gain a better understanding of these and other possible mechanisms of lovastatin during epileptogenesis

Acknowledgements - The authors would like to thank Hilda S. Reis for her help with histological techniques and Jaqueline Botelho her help in cell counts analysis. FAEP, FAPESP, CNPq and CAPES supported this study.

\section{REFERENCES}

1. Lowenstein DH, Alldredge BK. Current concepts: status epilepticus. N Engl J Med 1998;388:970-976.

2. Treiman DM. Therapy of status epilepticus in adults and children. Curr Opin Neurol. 2001;14:203-210.

3. Turski WA, Cavalheiro EA, Schwarz M, Czuczwar SJ, Kleinrok Z, Turski L. Limbic seizures produced by pilocarpine in rats: behavioural, electroencephalographic and neuropathological study. Behav Brain Res 1983;9:315-335.

4. Cavalheiro EA. The pilocarpine model of epilepsy. Ital J Neurol Sci 1995;16:33-37.

5. Mello LEAM, Cavalheiro EA, Tan AM, et al. Circuit mechanisms of seizure in the pilocarpine model of chronic epilepsy: cell loss and mossy fiber sprouting. Epilepsia 1993;34:985-995

6. Mathern GW, Betram EH, Babb TL, Pretorius JK, Kuhlman PA, Mendoza D. In contrast to kindled seizures, the frequency of spontaneous epilepsy in the limbic status model correlates with greater aberrant fascia dentata excitatory and inhibitory axon sprouting, and increased staining for NMDA, AMPA and GABA receptors. Neuroscience 1997; 77:1003-1019.

7. Goldstein MR. Effects of lovastatin and pravastatin on coronary artery disease.Ann Intern Med 1994;120:811-812. 
8. Gutteridge JM, Halliwell B. Free radicals and antioxidants in the year 2000: a historical look to the future. Ann N Y Acad Sci 2000;899:136-147.

9. Ku reishi Y, Luo Z, Shiojima I, et al. The HMG-CoA reductase inhibitor simvastatin activates the protein kinase Akt and promotes angiogenesis in normocholesterolemic animals. Nat Med 2000;6:1004-1010.

10. Pahan K, Sheikh FG, Namboodiri AM, Singh I, Lovastatin and phenylacetate inhibit the induction of nitric oxide synthase and cytokines in rat primary astrocytes, microglia, and macrophages. J Clin Invest1997; 100:2671-2679.

11. Aviram. M, Rosenblat M, Bisgaier CL, Newton RS. Atorvastatin and gemfibrzil metabolites, but not the parent drugs, are potent antioxidants against lipoprotein oxidation. Atheroscle rosis 1998;138:271-280.

12. Sironi L, Cinino M, Guerrini $U$, et al. Treatment with statins after induction of focal ischemia in rats reduces the extent of brain damage. Arterioscler Thromb Vasc Biol. 2003;23:322-327.

13. Mouritzen-Dam A. Hippocampal neurons loss in epilepsy and after experimental seizures. Acta Neurol Scand 1992;66:601-642.

14. Daimon A, Shigeyuki A, Takakazu K, Kurosawa H. Pravastatin, a 3hydroxy-3-methylglutaryl coenzyme A reductase inhibitor, reduces delayed neuronal death following transient forebrain ischemia in the adult rat hippocampus. Neurosci Lett 2004;362:122-126.

15. Bonfoco E, Krainc D, Ankarcrona M, Nicotera P, Lipton AS. Apoptosis and necrosis: two distinct events induced, respectively, by mild and intense insults with N-methyl-D-aspartate or nitric oxide/superoxide in cortical cell cultures. Proc Natl Acad Sci 1995;92:7162-7166.

16. B ruce AJ, Baudry M. Oxygen free radicals in rat limbic structures after kainate-induced seizures. Free Radic Biol Med 1995;18:993-1002.

17. Ueda Y, Yokoyama H, Niwa R, Konaka R, Ohya-Nishiguchi H, Kamada $\mathrm{H}$. Generation of lipid radicals in the hippocampal extracellular space during kainic acid-induced seizures in rats. Epilepsy Res 1997;26:329-333.

18. Cavalheiro EA, Leite JP, Bortolotto ZA, Turski WA, Ikonomidou C,
Turski L. Long-term effects of pilocarpine in rats: structural damage of the brain triggers kindling and spontaneous recurrent seizures. Epilepsia 1991;32:778-782.

19. Schulz JB, Henshaw DR, Siwek D, et al. Involvement of free radicals in excitotoxicity in vivo. J Neurochem. 1995;64:2239-2247.

20. Chen L, Haught WH., Yang B, Saldeen TGP, Parathasarathy S, Metha JL. Preservation of endogenous antioxidant activity and inhibition of lipid peroxidation as common mechanisms of antiatherosclerotic effects of vitamin E, lovastatin and amlodipine. J Am Coll Cardiol 1997;30:569-575.

21. Meldrum BS. Amino acid neurotransmitters in new approaches to anticonvulsant drug action. Epilepsia 1984;22:140-149.

22. Garthwaite J. Glutamate, nitric oxide and cell-cell signalling in the nervous system. Trends Neurosci 1991;14:60-67.

23. De Sarro GB, Donato Di Paola E, Sarro A, Vidal JM. Role of nitric oxide in the genesis of excitatory amino acid-induced seizures from the deep prepiriform cortex. Fundam Clin Pharmacol 1991;5:503-511.

24. Mulsch A, Busse R, Mondvintcev PL, et al. Nitric oxide promotes seizure activity in kainate-treated rats. Neuroreport 1994;21:2325-2328.

25. Moncada S,. Palmer RMJ, Higgs AS. Nitric oxide: physiology, pathophysiology, and pharmacology. Pharmacol Rev 1991;43:109-142.

26. Fewell JE, Johnson P. Acute increases in blood pressure cause arousal from sleep in lambs. Brain Res 1994;311:259-265.

27. Laufs U, Gertz K, Huang P, et al. Atorvastatin upregulates type III nitric oxide synthase in thrombocytes, decreases platelet activation, and protects from cerebral ischemia in normocholesterolemic mice. Stroke 2000;31:2442-2449.

28. Rothwell NJ. Annual review prize lecture cytokines - killers in the brain? J Physiol 1999;514:3-17

29. Minami M, Kuraishi $Y$, Satoh M. Effects of kainic acid on messenger RNA levels of IL-1 beta, IL-6, TNF alpha and LIF in the rat brain. Biochem Biophys Res Commun. 1991;176:593-598. 